\title{
Implementasi Berpikir Kritis dan Kreatif dalam Pembelajaran PPKn di SMP Negeri 8 Kota Padang
}

\author{
Bobby Serano, Maria Montessori \\ Prodi Pendidikan Pancasila dan Kewarganegaraan \\ FIS Universitas Negeri Padang \\ E-mail: mariamontessori@fis.unp.ac.id
}

\section{ABSTRAK}

Penelitian ini bertujuan untuk mendeskripsikan implementasi berpikir kritis dan kreatif dalam pembelajaran. Penelitian ini dilatarbelakangi oleh banyak siswa yang kurang aktif saat proses pembelajaran berlangsung dan ketakutan siswa untuk bertanya dan menjawab pertanyaan yang diberikan oleh guru. Dalam penelitian ini, peneliti mencoba untuk melihat dan mendeskripsikan mengenai bagaimana cara guru-guru di SMP Negeri 8 Kota Padang dalam mengembangkan kemampuan berpikir kritis dan kreatif peserta didik. Jenis Penelitian ini adalah penelitian kualitatif dengan menggunakan metode deskriptif. Penentuan informan dalam penelitian ini menggunakan teknik purposive sampling, sementara teknik pengumpulan data yang digunakan adalah observasi, wawancara, dan dokumentasi. Uji keabsahan dilakukan dengan menggunakan teknik triangulasi sumber data yang diperoleh selama penelitian dianalisis dengan cara reduksi data, penyajian data, dan penarikan kesimpulan/verifikasi. Hasil Penelitian menunjukan bahwa guru PPKn di SMP Negeri 8 Padang secara umum sudah mengimplementasikan kemampuan berpikir kritis dan kreatif. Dalam mengembangkan kemampuan berpikir ini, guru-guru telah membuat rancangan pembelajaran dengan indikator yang merangsang anak untuk berpikir kritis dan kreatif contohnya dengan memakai kata kerja oprasional ranah kognitif menganalis, evaluasi, dan kreasi dari taksonomi bloom yang merangsang peserta didik untuk berpikir tingkat tinggi.

Kata Kunci: implementasi, berfikir kritis, berfikir kreatif, pembelajaran PPKn

\section{ABSTRACT}

This study aims to describe the implementation of critical and creative thinking in civic learning. This research is based on the fact that many students tend to be less active during the learning process and have fear to ask and answer questions given by teachers. In this study, the researcher tried to see and describe how the teachers at SMP Negeri 8 Kota Padang develop students' critical and creative thinking skills. This research is qualitative research that uses descriptive approach. Determination of informants in this study proposed by using purposive sampling techniques while the data collection techniques used are observation, interview, and documentation. The validity test for this study uses triangulation techniques. The data sources obtained during the study were analyzed by means of data reduction, data presentation, and conclusion/verification withdrawal. The results showed that civic teachers at SMP Negeri 8 Padang in general have implemented 
critical and creative thinking skills. In developing this thinking ability, the teachers have created a learning design with indicators that stimulate children to think critically and creatively, for example by using operational verbs in the cognitive realm of analyzing, evaluating, and creating from bloom taxonomy that stimulates learners to think high levels. Keywords: critical and creative thinking, civic education

\section{PENDAHULUAN}

Permendikbud No.58 Tahun 2014 secara eksplisit menyebutkan bahwa tujuan PPKn adalah untuk membentuk peserta didik memiliki kecakapan dalam berpikir secara kritis, rasional, dan kreatif. Demi mewujudkan tujuan ini, diperlukan pembelajaran yang mengimplementasikan kemampuan berpikir kritis dan kreatif. Montessori (2002: 54), menyatakan bahwa Pendidikan Pancasila dan Kewarganegaraan (PPKn) adalah salah satu bidang studi yang bertujuan untuk mendidik warga negara menjadi aktif, partisipatif, dan melatih siswa untuk berpikir pada taraf yang lebih tinggi. Oleh karena itu, kemampuan berpikir kritis dan kreatif sangat penting dimiliki oleh seorang siswa karena kemampuan berpikir ini akan melatih siswa untuk memiliki kemampuan berpikir secara rasional dan inovatif.

Kemampuan berpikir kritis dan kreatif dapat dikembangkan oleh guru dengan memilih dan menggunakan metode, strategi, maupun pendekatan yang dapat melibatkan siswa aktif dalam pembelajaran, baik secara fisik, mental maupun sosial. Dalam perkembangannya, penelitian dengan perhatian terkait hal ini telah diteliti di berbagai mata pelajaran, seperti yang telah dilakukan oleh Amasari (2011) yang meneliti tentang upaya pengembangan kemampuan berpikir kritis dan kreatif di SMK Negeri 1 Depok dalam pembelajaran MTK. Hasil penelitian ini menyebutkan bahwa pembelajaran matematika dengan metode Problem Posing tipe Pre solution Posing berjalan dengan baik dan dapat meningkatkan kemampuan berpikir kritis dan kreatif siswa. Penelitian selanjutnya oleh Kurniawati (2015), yang meneliti tentang penerapan pembelajaran Problem Base Learning untuk meningkatkan kemampuan berpikir kritis dan kreatif pada pembelajaran Sosiologi. Hasil penelitian mendapati bahwa metode ini terbukti secara empiris dapat meningkatkan kemampuan berpikir kritis di SMA Negeri 5 Surakarta.

Salah satu sekolah yang menerapkan pembelajaran berpikir kritis dan kreatif adalah SMP Negeri 8 Kota Padang. Sekolah ini merupakan salah satu sekolah negeri di Kota Padang yang memiliki akreditasi A dan menempati peringkat 10 besar sekota Padang. Penulis telah mencari tahu kondisi pembelajaran PPKn di sekolah ini dengan melakukan wawancara dengan guru PPkn di sekolah tersebut, Ibu Rita Siswanti, 
S.Pd. Berdasarkan hasil wawancara tersebut (22 Juli 2020), yang dilakukan via telepon, diketahui bahwa implementasi berpikir kritis dan kreatif untuk siswa di SMP Negeri 8 Padang dalam pembelajaran PPKn cenderung masih tidak optimal, lantaran beberapa kondisi: 1) perbedaan kualitas siswa sejak sistem zonasi 2) siswa tidak memiliki kemauan kuat untuk aktif di kelas 3) siswa tidak memiliki minat membaca sehingga berkurangnya daya diskusi.

Fokus penelitian ini terletak pada bagaimana implementasi berpikir kritis dan kreatif dalam pembelajaran PPKn di SMP Negeri 8 Kota Padang. Adapun manfaat yang diharapkan dalam penelitian ini, adalah untuk dapat berguna untuk memberikan masukan bagi guru PPKn supaya dapat mengoptimalkan pengembangan pembelajaran berbasis pada kemampuan berpikir kritis dan kreatif di dalam kelas, juga, diharapkan siswa dapat menerima pembelajaran PPKn dengan penerapan berpikir kritis dan kreatif yang telah teroptimalkan.

\section{METODE PENELITIAN}

Penelitian ini menggunakan jenis penelitian kualitatif dengan menggunakan metode deskriptif. Adapun metode deskriptif tersebut merupakan suatu metode yang bertujuan untuk mendeskripsikan atau menggambarkan secara sistematis, faktual, dan akurat mengenai fakta-fakta, sifat-sifat serta hubungan antar fenomena yang diteliti. Dua puluh orang terdiri dari guru dan siswa SMP Negeri 8 Kota Padang dijadikan sebagai sumber data. Mereka terdiri dari satu orang Kepala Sekolah, satu Wakil Kepala Sekolah, tiga orang guru PPKn dan lima belas orang siswa. Data ini diperoleh menggunakan teknik observasi, wawancara, dan studi dokumentasi. Selanjutnya, untuk menguji keabsahan data, penulis menggunakan teknik triangulasi sumber. Sebagaimana telah digambarkan oleh Miles dan Huberman dalam Ahmad (214: 231), yang harus dilakukan dalam menganalisis ialah dengan mengumpulkan data, reduksi data, dan penarikan kesimpulan.

\section{HASIL DAN PEMBAHASAN}

Implementasi Berpikir Kritis dan Kreatif di SMP Negeri 8 Kota Padang

Paul dan Elder (dalam Nafiah dan Wardan: 2008) mengatakan bahwa seseorang dapat dikatakan berpikir kritis dengan baik jika; 1) Mengajukan pertanyaan penting terhadap masalah, 2) Mengumpulkan dan menilai informasi yang relevan, 3) Membuat kesimpulan dan solusi dengan penalaran yang tepat, 4) Berpikir dengan pikiran terbuka 5) Berkomunikasi efektif dalam menyampaikan solusi dari permasalahan.

Menurut Arini \& Asmila (2017), Kemampuan berpikir kreatif dapat diukur dengan melihat pada empat karakteristik dalam kemampuan berpikir kreatif yaitu berpikir dengan lancar (fluency), berpikir seecara luwes (flexibility), berpikir dengan hasil yang orisinal (originality), dan penguraian (elaboration). Beberapa manfaat berpikir kritis menurut Eliana Crespo (dalam Zakiah dan Ika, 2019), untuk performa akademis, yaitu: 1) Memahami argumen dan kepercayaan orang lain, 2) Mengevaluasi secara kritis argumen dan kepercayaan itu, 3) Mengembangkan dan mempertahankan argumen dan 
kepercayaan diri untuk didukung dengan baik. menurut Johnson (dalam Marliani, 2015), manfaat berpikir kreatif sangat luas dan tak terbatas sehingga dapat menemukan hal-hal yang sama sekali tidak lazim atau baru dapat berupa ide ataupun gagasan yang terbarukan. Maka, pembelajaran PPKn perlu dilaksanakan dengan menerapkan berpikir kritis agar mahasiswa menjadi warga negara yang dapat menganalisis berbagai masalah secara terbuka dan mampu membuat keputusan solutif dalam hidup mereka (Maria: 2020).

Implementasi berpikir kritis dan kreatif dalam pembelajaran PPKn di SMP Negeri 8 Padang dapat dilihat dari beberapa tahapan: tahap perencanaan; tahap pelaksanaan; dan tahap penilaian. Dari tahapan-tahapan ini akan dilihat bagaimana implementasi berpikir kritis dan kreatif dalam pembelajaran PPKn. Pertama tahap perencanaan: Guru berusaha merancang rencana yang matang agar tujuan pengembangan kemampuan berpikir siswa dapat dilaksanakan dengan maksimal, seperti dengan melihat terlebih dahulu kompetensi inti, kompetensi dasar, indikator dan alokasi waktu yang ada di buku pedoman guru. Selain itu, guru juga merumuskan tujuan pembelajaran, metode pembelajaran, kegiatan pembelajaran, dan menentukan penilaian seperti apa yang ingin dicapai.

Kedua tahap pelaksanaan: Guru memberikan pertanyaan-pertanyaan untuk dijawab peserta didik sebelum memulai pelajaran dan memberikan tugas kepada peserta didik untuk membuat pertanyaan-pertanyaan dan jawaban sendiri berdasarkan indikator pencapaian yang diterapkan ke dalam proses pelaksanaan pembelajaran. Dengan dilakukannya usaha ini, peserta didik diharapkan mampu menerapkan berpikir kritis dan kreatif. Pemilihan model atau metode pembelajaran yang digunakan telah disesuaikan dengan kompetensi seperti apa yang diinginkan contohnya, problem base learning dan discovery learning.

Juga, pertanyaan-pertanyaan yang dibuat harus bisa memancing siswa untuk berpikir ke taraf yang lebih tinggi seperti (kenapa, mengapa, dan bagaimana). Usaha alternatif juga diusahakan ke dalam pelaksanaan pembelajaran dengan memasukan muatan-muatan materi yang sifatnya religius, seperti mengaitkan materi pembelajran dengan ayat di dalam AlQuran untuk mendorong kemampuan berpikir kritis dan kreatif siswa. Ketiga tahap penilaian: Bentuk nilai yang diberikan guru menggunakan "symbol-simbol" di belakang nilai. Contohnya, "100 HLB". HLB adalah Hebat Luar Biasa, yang dianggap sebagai nilai plus untuk nilai 100 . Bentuk penilaian ini dapat sekaligus memotivasi iswa untuk lebih aktif dan lebih kreatif dalam menjawab pertanyaan.

\section{KESIMPULAN}

Berdasarkan uraian di atas, dapat penulis simpulkan bahwa implementasi berpikir kritis dan kreatif dalam pembelajaran PPKn di SMP Negeri 8 Padang secara umum sudah diimplementasikan sampai pada tahap penilaian. Dalam mengembangkan kemampuan berpikir ini guru-guru telah membuat rancangan pembelajaran dengan indikator yang merangsang peserta didik untuk berpikir kritis dan kreatif. 
Contohnya dengan memakai kata kerja oprasional di ranah kognitif seperti menganalis, evaluasi, dan kreasi. Dalam pelaksanaannya guru juga sudah mengguankan metodemetode yang dapat memancing kemampuan berpikir peserta didik mulai dari problem solving, discovery learning, dan mengadaptasi teori punish and reward tak sampai di situ guru juga menggunakan ayat yang terdapat di dalam Al-Quran sebagai alternatif pembelajaran. Tugas, pertanyaaan, dan ulangan-ulangan yang diberikan ke peserta didik juga sudah meletakan komponenkomponen yang dapat membuat siswa berpikir tingkat tinggi seperti kenapa, mengapa, dan bagaimana.

\section{DAFTAR PUSTAKA}

Amasari, F. H. (2011). Upaya Meningkatkan Kemampuan

Berpikir Kritis dan Kreatif Siswa Kelas X Administrasi Perkantoran (AP) SMK Negeri 1 Depok pada pembelajaran Matematika dengan Metode Problem Posing Tipe Proselution Posing. Universitas Negeri Yogyakarta.

Arini, W., \& Asmila, A. (2017). Analisis kemampuan berpikir kreatif pada materi cahaya siswa kelas viii smp xaverius kota lubuklinggau. 1(1).

Azwar, A. (2012). Pendidikan Kewarganegaraan dan Pendidikan Karakter Bangsa. Jurnal Demokrasi, 11(1).
Dianti, P., Kewarganegaraan, P. P., \& Yunani, S. F. (2014). Integrasi Pendidikan Karakter Dalam Pembelajaran. 23(1), 58-68.

Kurniawati, D. K. (2015). Penerapan Model Pembelajaran Problem Base Learning Untuk Meningkatkan Kemampuan Berpikir Kritis Siswa pada Mata Pelajaran Sosiologi Semester Genap Kelas XI IIS 3 SMAN 5 Surakarta.

Montessori, M. (2002). Pendidikan Kewarganegaraan dan Keterampilan Berpikir. Demokrasi, 1(1).

Montessori, M. Indrawadi, J. Tiara, M. (2020). Analysis of Teacher Questions in Improving High Order Thinking Skills of Students Through Learning of Pancasila and Civic Education. Proceedings of the International Conference On Social Studies, Globalisation And Technology (ICSSGT 2019). Advances in Social Science, Education and Humanities Research, volume 458.

Nafiah, Yunin Nurun dan Wardan Suryanto. Penerapan Model Base Learning untuk meningkatkan keterampilan berpikir kritis dan hasil belajar siswa. Jurnal Pendidikan Vokasi.

Permendikbud No. 58 tahun 2014 tentang tujuan pembelajaran PPKn 